Jurnal Gizi dan Dietetik Indonesia

Vol. 5, No. 1, 2017: 1-8
Tersedia online pada: http://ejournal.almaata.ac.id/index.php/IJND DOI : http://dx.doi.org/10.21927/ijnd.2017.5(1).1-8

\title{
Penurunan total polifenol, etanol, asam laktat, asam asetat, dan asam amino selama fermentasi biji kakao asalan dengan penambahan inokulum
}

\author{
Mulono Apriyanto', Rujiah² \\ ${ }^{1}$ Prodi Teknologi Pangan Fakultas Pertanian Universitas Islam Indragiri, \\ Jl. Propinsi Parit 1 Tembilahan Hulu Kab.Indragiri Hilir, \\ e-mail: mulonoapriyanto71@gmail.com \\ ${ }^{2}$ Badan Ketahanan Pangan Kabupaten Indragiri Hilir \\ JI. Diponegoro No.52 Tembilahan-Indragiri Hilir
}

\begin{abstract}
ABSTRAK
Latar belakang: Biji kakao kering ditingkat petani sebagian besar dihasilkan tanpa fermentasi tidak menghasilkan prekursor flavour khas kakao. Upaya untuk mendapatkan biji kakao kering yang memiliki prekursor flavour khas kakao dapat dilakukan apabila terdapat subtrat yang dapat difermentasi oleh mikrobia yang terlibat dalam fermentasi biji kakao segar dengan kondisi proses yang sesuai

Tujuan: Mengetahui pengaruh variasi teknik fermentasi biji kakao asalan terhadap parameter mutu biji kakao asalan hasil fermentasi, dan mengevaluasi prekursor flavour dan senyawa volatil yang dihasilkan biji kakao hasil fermentasi pasca sangrai.

Metode: Tahapan penelitian yang dilakukan adalah 3 variasi teknik fermentasi yaitu pertama perlakuan tanpa penambahan inokulum (kontrol), kedua menggunakan inokulum S. cerevisiae (FNCC 3056), L. lactis (FNC 0086) dan A. aceti (FNCC 0016), masing-masing sekitar $10^{8} \mathrm{cfu} / \mathrm{g}$ diberikan serentak di awal fermentasi (IA). Ketiga, pemberian inokulum secara bertahap yeast di awal fermentasi, bakteri asam laktat padajam ke-24, dan bakteri asam asetat pada jam ke 48 dengan populasi mikrobia sama dengan perlakuan kedua (IB). Fermentasi dilaksanakan selama 120 jam. Suhu diatur selama fermentasi, berturut-turut $35^{\circ} \mathrm{C}$

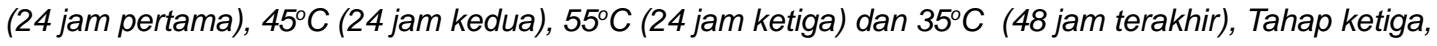
biji kakao hasil fermentasi dari tiga perlakuan tersebut disangrai dan dianalisis senyawa volatilnya.

Hasil: Hasil penelitian menunjukkan bahwa selama fermentasi biji kakao asalan menunjukan total polifenol turun pada ketiga perlakuan. Biji kakao asalan pasca fermentasi menghasilkan asam amino hidrofobik yaitu alanin, tirosin, valin, phenilalanin, isoleusin dan methionin sebagai prekursor flavor dengan total asam amino hidrofobik dimiliki oleh perlakuan penambahan inokulum secara serentak.

Kesimpulan: Rehidrasi pulp biji kakao asalan dapat memperbaiki komposisi pulp sebagai subtrat fermentasi. Parameter pengujian, prekursor aroma dan senyawa volatil tertinggi ditunjukkan pada perlakuan penambahan inokulum secara bertahap.
\end{abstract}

KATA KUNCI: biji kakao asalan, fermentasi, inokulum, polifenol dan asam amino hidrofobik

\section{Decrease of polyphenols, ethanol, lactic acid, acetic acid, and amino acid during fermentation with addition of cocoa beans innoculum ABSTRACT}

\footnotetext{
Background: Farmers mostly produced dry beans without fermentation. Attempts to get dry cocoa beans that have a typical cocoa flavor precursors can be done if there is still a substrate which can be fermented by microbes involved in the fermentation of fresh cocoa beans with the appropriate process conditions. Objectives: To evaluate the effect of variety of techniques fermentation of cocoa beans randomly to quality parameters of fermented cocoa beans, and evaluate the precursors of flavor and volatile compounds produced after roasting.

Methods: Stages of the research were as follows: fermentation technique was done 3 variations of fermentation technique that were the first, treatment without the addition of inoculum (control), second,
} 
treatment with inoculum of S. cerevisiae (FNCC 3056), L. lactis (FNC 0086) and A. aceti (FNCC 0016), about $10^{8} \mathrm{cfu} / \mathrm{g}$ of microbes at the beginning of fermentation (IA). Third, yeast inoculum at the start of fermentation, lactic acid bacteria on the hour of 24 and acetic acid bacteria at 48 hours, with the same mount of microbial population with the second treatment (IB). Fermentation was conducted during 120 hours. Temperature was adjusted during fermentation, that were $35^{\circ} \mathrm{C}$ the first (24 hours), $45^{\circ} \mathrm{C}$ (the second 24 hours), $55^{\circ} \mathrm{C}$ (the third 24 hours) and $35^{\circ} \mathrm{C}$ (the fourth 24 hours). At the end of stage, fermented cocoa beans were roasted and analyzed for its volatile compound.

Results: The results showed that total plyphenols decrease in all treatments during fermentation. It have been to produce hydrophobic amino acids, that were: alanine, tyrosine, valine, phenilalanin, isoleucine and methionin as precursors of flavor with a total of hydrophobic amino acids were owned all treatment.

Conclusions: Parameter testing, like aroma precursors and volatile compounds in the treatment shown the highest increase gradually inoculum.

KEYWORDS: cocoa beans, fermentation, inoculum, poliphenol, and amino acid

\section{PENDAHULUAN}

Produksi biji kakao kering dari perkebunan rakyat pada umumnya tidak menggunakan proses fermentasi baik secara alami maupun dengan penambahan inokulum. Pada umumnya petani kakao hanya merendam biji kakao segar dalam air dalam upaya untuk membantu menghilangkan pulp dan menjemur. Biji kakao kering yang tidak diketahui kadar airnya, dijual tanpa memperhatikan kualitas baik dari aspek kadar air maupun kondisi biji kering disebut sebagai biji kakao asalan.

Fermentasi adalah salah satu faktor penting dalam pengolahan biji kakao khususnya dalam pembentukan senyawa prekusor flavor. Proses fermentasi kakao umumnya berlangsung secara alami dibantu oleh mikrobia dari udara berlangsung selama 6 hari serta dilakukan pembalikan pertama di hari ke-2 dan selanjutnya dilakukan pada setiap 24 jam (1). Aktivitas mikrobia tersebut menghasilkan etanol, asam laktat, dan asam asetat selama fermentasi yang diikuti oleh kenaikan suhu lingkungan fermentasi. Alkohol dan asam asetat didifusi kedalam biji kakao dan diikuti oleh kenaikan suhu yang berdampak pada kematian biji (tidak dapat berkecambah). Reaksi hidrolitik dalam biji kakao diawali oleh kematian biji sehingga struktur kotiledon biji berubah lebih berongga dan kotiledon berwarna coklat.

Cita rasa dan aroma khas cokelat (flavor cokelat) ditentukan oleh mutu kakao. Aroma khas cokelat baru akan timbul pada saat penyangraian. Prekusor aroma yang terbentuk selama fermentasi dikembangkan pada proses penyangraian melalui reaksi kimia non enzimatis yang memegang peranan penting pada pembentukan flavor yaitu reaksi Maillard. Prekusor aroma yang penting dalam reaksi Maillard adalah gula reduksi (glukosa) dan asam amino hidrofobik. Asam amino bebas hidrofobik yang dihasilkan selama fermetasi biji kakao antara lain: alanin, valin, leusin, fenilalanin, tirosin, dan isoleusin. Prekursor aroma yang dihasilkan dari reaksi asam amino dan gula reduksi antara lain aldehid, asam, alkohol dan ester (2-4). Pasca biji kakao disangrai dihasilkan senyawa volatil khas yaitu 2-metil pirazin, 2,5-dimetil-, 2,3-dimetil-, 2,3,5trimetil-, dan 2,3,5,6-tetrametilpirazin (5).

Hasil penelitian (6) dan (7) menunjukkan bahwa komposisi pulp biji kakao kering dapat digunakan sebgai subtrat fermentasi dengan berbagai perlakuan awal seperti pengembalian kadar air pulp dan penembahan tetes tebu (8), menunjukkan bahwa penambahan Sacharomyces cerevisiae, Lactobacillus lactis dan Acetobacter aceti dapat meningkatkan populasi yeast, bakteri asam laktat, bakteri asam asetat, suhu fermentasi dan memperpendek waktu fermentasi. Pembeda penelitian ini dengan penelitian sebelumnya adalah perbaikan mutu hasil fermentasi biji kakao kering tidak saja didasarkan pada indeks fermentasi, tetapi juga penurunan total polifenol dan asam amino hidrofobik yang terbentuk.

Penelitian ini bertujuan untuk mengetahui penurunan total polifenol dan asam amino hidrofobik yang terbentuk selama fermentasi. 


\section{BAHAN DAN METODE}

Buah kakao jenis lindak (bulk cacao) diperoleh dari desa Bunder, Patuk, Gunung Kidul, Yogyakarta dengan karakteristik yang dimiliki yaitu panjang buah $\pm 15 \mathrm{~cm}$, diameter $\pm 8 \mathrm{~cm}$, kulit buah masak optimal berwarna orange, jumlah biji tiap pod \pm 35 keping biji.

Inokulum S. cerevisiae (FNCC 3056), L. lactis (FNC 0086) dan A. aceti (FNCC 0016) diperoleh dari Laboratorium Mikrobiologi Pusat Studi Pangan dan Gizi Universitas Gadjah Mada. Aseton $80 \%$, BSA (bovien serum albumin), buffer fosfat, asam asetat, trichloroacetat acid, $\mathrm{HCl}$, larutan buffer $\mathrm{pH} 4, \mathrm{pH} 7$ dan $\mathrm{pH}$ 9, hexana, Iarutan Folin-Ciocalteu, $\mathrm{Na}_{2} \mathrm{CO}_{3}$ seluruh bahan kimia yang digunakan berstandar PA (Pro Analit).

Eluent $A$ terdiri dari buffer asam asetat : $50 \mathrm{mM}$ Natrium asetat: Tetrahydrofuran (THF) $(2: 96: 2) \mathrm{pH}$ 6,8 sebagai fase diam. Eluent $B$ terdiri atas asam asetat $65 \%$ sebagai fase gerak. Eluent $A$ terdiri dari buffer asam asetat: $50 \mathrm{mM}$ Natrium asetat : THF (2:96:2) $\mathrm{pH}$ 6,8 sebagai fase diam. Eluent B terdiri atas asam asetat $65 \%$ sebagai fase gerak. Kertas saring whatman nomer 1 . Media tumbuh mikrobia Peptone (oxoid), Glucose (oxoid), Yeast extract (oxoid), MRS broth (Oxoid), agar (Oxoid), $\mathrm{NaCl}$, $\mathrm{CaCO}_{3}$. Etanol 90\%. Reagensia Nelson A dan Nelson $\mathrm{B}$. $\mathrm{Pb}$ asetat. Semua bahan kimia yang digunakan untuk keperluan penelitian adalah katagori Pro Analis (PA-Grade). Penelitian telah dilaksanakan di Laboratorium Rekayasa Pusat Studi Pangan dan Gizi, Fakultas Teknologi Pertanian Universitas Gadjah Mada. Parameter pengujian total polifenol mengacu metoda Noor-Soffalina et al, 2009 (9), parameter asam amino mengacu metoda Ikrawan et al, 1997 (10). Data seluruhnya dianalisis statistik secara oneway Anova pada tingkat signifikasi 95\% jika berbeda nyata dilanjutkan dengan uji lanjut LSD (least Significant different) menggunakan program software pengolah data.

Penelitian ini menggunakan tiga teknik fermentasi. Ketiga variasi teknik fermentasi yaitu tanpa penambahan inokulum (kontrol), perlakuan kedua menggunakan inokulum S. cerevisiae (FNCC 3056), L. lactis (FNC 0086) dan A. aceti (FNCC 0016), masing-masing sekitar $10^{8} \mathrm{cfu} / \mathrm{g}$ diberikan serentak di awal fermentasi (IA) dan perlakuan ketiga, pemberian inokulum secara bertahap yaitu yeast di awal fermentasi, bakteri asam laktat pada jam ke-24 dan bakteri asam asetat pada jam ke-48 dengan populasi mikrobia sama dengan perlakuan kedua (IB). Fermentasi dilaksanakan selama 120 jam. Suhu diatur selama fermentasi, berturut-turut $35^{\circ} \mathrm{C}$ (24 jam pertama), $45^{\circ} \mathrm{C}$ ( 24 jam kedua), $55^{\circ} \mathrm{C}$ (24 jam ketiga) dan $35^{\circ} \mathrm{C}$ (48 jam terakhir) (IC).

\section{HASIL}

Hasil penelitian menujukkan bahwa total polifenol biji kakao turun dari hasil perlakuan kontrol, penambahan inokulum secara serentak dan secara bertahap berturut-turut dari 0,$17 ; 0,18$ dan 0,17 meq asam galat/g menjadi berturut - turut 0,$08 ; 0,07$ dan $0,06 \mathrm{meq}$ asam galat/g seperti tersaji pada Gambar 1.

Hasil penelitian menunjukkan bahwa total asam amino hidrofobik seluruh perlakuan mengalami kenaikan selengkapnya tersaji pada Tabel 1, 2 dan 3.

\section{BAHASAN}

Hubungan antara kosentrasi asam asetat terhadap perubahan polifenol selama fermentasi tersaji pada Gambar 1. Hasil penelitian ini menunjukkan bahwa seiring kosentrasi asam asetat naik, maka total polifenol turun. Asam asetat merupakan asam organik yang terdifusi ke dalam keping biji sehingga mengakibatkan aktifnya enzim polifenol oksidase yang mengoksidasi polifenol. Pada 72 jam fermentasi, total polifenol perlakuan kontrol, IA dan IB berturut-turut yaitu 0,102; 0,099 dan 0,092 $\mathrm{mg}$ asam galat/g, dengan kosentrasi asam asetat berturut-turut yaitu 3,46; 3,53 dan $3,32 \%$. Pada 108 jam fermentasi, konsentrasi asam asetat perlakuan kontrol, IA dan IB menunjukkan kosentrasi tertinggi masing-masing yaitu 5,$94 ; 6,31$ dan $6,83 \%$.

Pada 108 jam fermentasi total polifenol pada perlakuan kontrol, pada penambahan inokulum secara serentak, dan secara bertahap fermentasi menunjukkan nilai terendah berturut - turut 


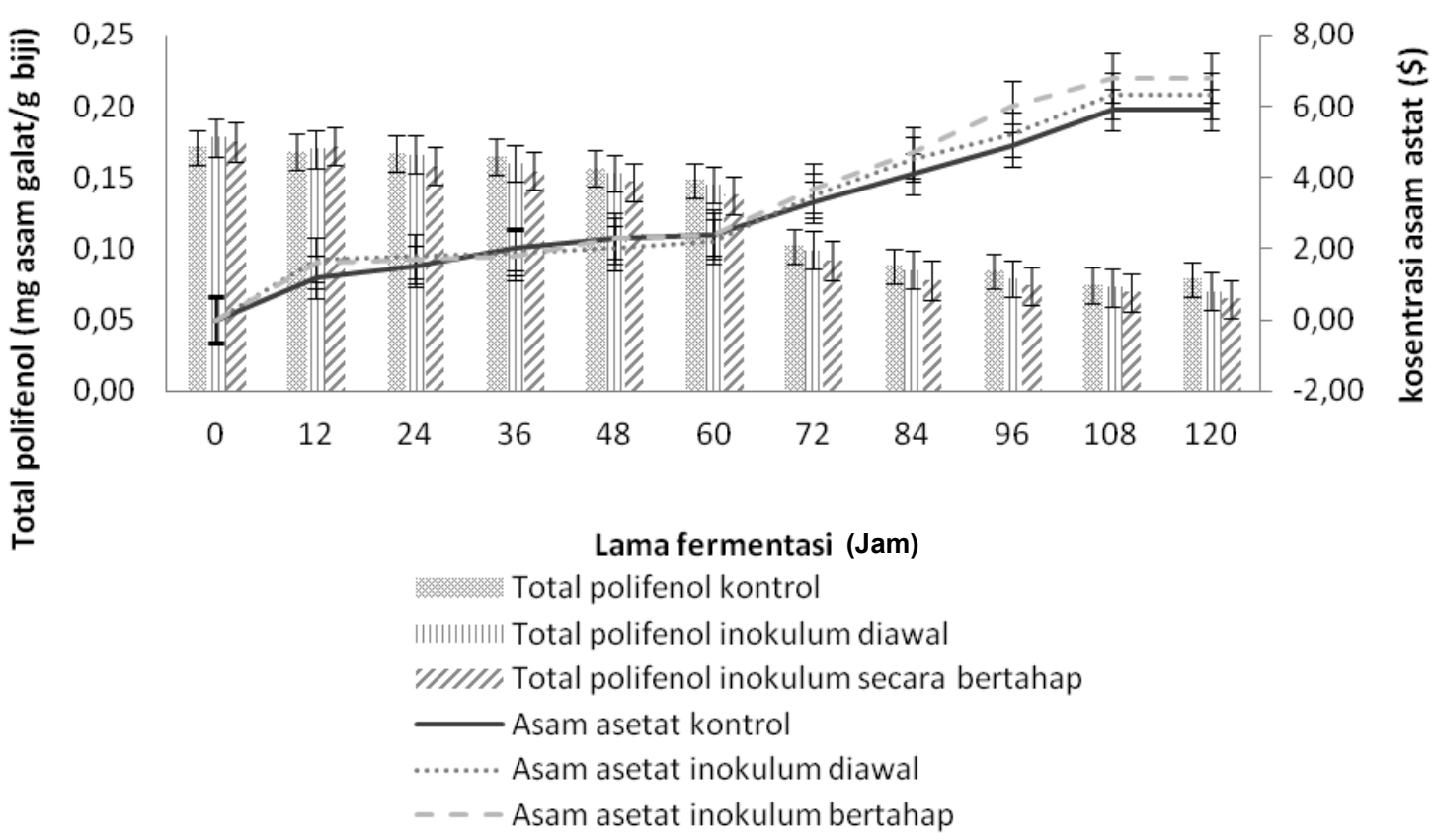

Gambar 1. Hubungan kosentrasi asam asetat terhadap perubahan total polifenol biji kakao hasil perlakuan kontrol, penambahan inokulum secara serentak dan secara bertahap

Tabel 1. Kandungan asam amino bebas biji kakao hasil perlakuan kontrol selama fermentasi berturut - turut 72,96 dan 120 jam $(\mu \mathrm{g} / \mathrm{g})$

\begin{tabular}{lcccc}
\hline \multirow{2}{*}{ Asam Amino } & \multicolumn{4}{c}{ Lama fermentasi (jam) } \\
\cline { 2 - 5 } & $\mathbf{0}$ & $\mathbf{7 2}$ & $\mathbf{9 6}$ & $\mathbf{1 2 0}$ \\
\hline Hidrofobik & $1,37 \mathrm{ab}$ & $1,32 \mathrm{a}$ & $1,75 \mathrm{~b}$ & $1,65 \mathrm{ab}$ \\
Alanin & $0,78 \mathrm{a}$ & $0,69 \mathrm{a}$ & $0,61 \mathrm{a}$ & $0,63 \mathrm{a}$ \\
Tirosin & $0,82 \mathrm{a}$ & $0,95 \mathrm{a}$ & $0,87 \mathrm{a}$ & $0,95 \mathrm{a}$ \\
Valin & $1,26 \mathrm{a}$ & $1,18 \mathrm{a}$ & $1,03 \mathrm{a}$ & $1,19 \mathrm{a}$ \\
Phenilalanin & $0,92 \mathrm{a}$ & $0,87 \mathrm{a}$ & $0,82 \mathrm{a}$ & $0,92 \mathrm{a}$ \\
Isoleusin & $1,41 \mathrm{a}$ & $1,47 \mathrm{a}$ & $1,35 \mathrm{a}$ & $1,48 \mathrm{a}$ \\
Leusin & $0,65 \mathrm{a}$ & $0,64 \mathrm{a}$ & $0,63 \mathrm{a}$ & $0,64 \mathrm{a}$ \\
Methionin & 7,21 & 7,12 & 7,06 & 7,46 \\
Total & & & & \\
Asam & $3,21 \mathrm{~b}$ & $4,59 \mathrm{~b}$ & $4,65 \mathrm{~b}$ & $3,15 \mathrm{a}$ \\
Asam aspartat acid & $15,74 \mathrm{c}$ & $15,31 \mathrm{~b}$ & $14,89 \mathrm{a}$ & $15,31 \mathrm{~b}$ \\
Asam glutamat acid & $1,24 \mathrm{ab}$ & $1,19 \mathrm{a}$ & $1,30 \mathrm{ab}$ & $1,38 \mathrm{~b}$ \\
Serin & $0,79 \mathrm{ab}$ & $0,76 \mathrm{a}$ & $0,74 \mathrm{ab}$ & $0,77 \mathrm{~b}$ \\
Histidin & 20,98 & 21,85 & 21,58 & 20,61 \\
Total &
\end{tabular}

Keterangan : Huruf berbeda di belakang angka pada baris sama menunjukkan beda nyata pada $\mathrm{p} \leq 0,05$

Hasil rata-rata 2 ulangan dengan 3 ulangan analisis

yaitu 0,$074 ; 0,073$ dan 0,066 (mg asam galat/g). Penurunan total polifenol dan peningkatan kosentrasi asam asetat yang dihasilkan sesuai dengan hasil penelitian yang diperoleh Kustyawati dan Setyani (2008) (11) dan Mulono, et al (2016) (12), yang telah mempelajari penambahan inokulum mikrobia S. cerevisiae, $L$. lactis dan $A$. aceti pada fermentasi biji kakao segar varietas lindak.

Penurunan total polifenol selama fermentasi dapat diduga disebabkan oleh oksidasi aktivitas 
Tabel 2. Kandungan asam amino bebas biji kakao hasil perlakuan penambahan inokulum secara serentak selama fermentasi berturut-turut 72, 96 dan 120 jam $(\mu \mathrm{g} / \mathrm{g})$

\begin{tabular}{lcccc}
\hline \multirow{2}{*}{ Asam amino } & \multicolumn{4}{c}{ Lama Fermentasi (ja m) } \\
\cline { 2 - 5 } & $\mathbf{0}$ & $\mathbf{7 2}$ & $\mathbf{9 6}$ & $\mathbf{1 2 0}$ \\
\hline Hidrofobik & $1,57 \mathrm{ab}$ & $1,52 \mathrm{a}$ & $1,66 \mathrm{~b}$ & $1,61 \mathrm{ab}$ \\
$\quad$ Alanin & $0,85 \mathrm{a}$ & $0,77 \mathrm{a}$ & $0,61 \mathrm{a}$ & $0,62 \mathrm{a}$ \\
Tirosin & $0,94 \mathrm{a}$ & $1,07 \mathrm{a}$ & $0,99 \mathrm{a}$ & $1,06 \mathrm{a}$ \\
Valin & $1,43 \mathrm{a}$ & $1,35 \mathrm{a}$ & $1,19 \mathrm{a}$ & $1,35 \mathrm{a}$ \\
Phenilalanin & $1,02 \mathrm{a}$ & $0,96 \mathrm{a}$ & $0,97 \mathrm{a}$ & $1,07 \mathrm{a}$ \\
Isoleusin & $1,66 \mathrm{a}$ & $1,72 \mathrm{a}$ & $1,60 \mathrm{a}$ & $1,83 \mathrm{a}$ \\
Leusin & $0,72 \mathrm{a}$ & $0,71 \mathrm{a}$ & $0,70 \mathrm{a}$ & $0,72 \mathrm{a}$ \\
Methionin & 8,19 & 8,10 & 7.72 & 8,26 \\
Total & & & & \\
Asam & $3,81 \mathrm{~b}$ & $4,47 \mathrm{~b}$ & $4,53 \mathrm{~b}$ & $3,75 \mathrm{a}$ \\
Asam aspartat & $15,86 \mathrm{c}$ & $15,05 \mathrm{~b}$ & $15,03 \mathrm{a}$ & $15,42 \mathrm{~b}$ \\
Asam glutamat & $1,39 \mathrm{ab}$ & $1,25 \mathrm{a}$ & $1,35 \mathrm{ab}$ & $1,44 \mathrm{~b}$ \\
Serin & $0,82 \mathrm{ab}$ & $0,81 \mathrm{a}$ & $0,78 \mathrm{ab}$ & $0,80 \mathrm{~b}$ \\
Histidin & 21,88 & 21,58 & 21,69 & 21,41 \\
Total & &
\end{tabular}

Keterangan : Huruf berbeda di belakang angka pada baris sama menunjukkan beda nyata pada $p<0,05$

Hasil rata-rata 2 ulangan dengan 3 ulangan analisis

Tabel 3. Kandungan asam amino bebas biji kakao kering hasil perlakuan penambahan inokulum secara bertahap selama fermentasi berturut - turut 72,96 dan 120 jam ( $\mu \mathrm{g} / \mathrm{g})$

\begin{tabular}{lcccc}
\hline \multirow{2}{*}{ Asam Amino } & \multicolumn{4}{c}{ Lama fermentasi (jam) } \\
\cline { 2 - 5 } & $\mathbf{0}$ & $\mathbf{7 2}$ & $\mathbf{9 6}$ & $\mathbf{1 2 0}$ \\
\hline Hidrofobik & & & & \\
Alanin & $1,59 \mathrm{ab}$ & $1,55 \mathrm{a}$ & $1,65 \mathrm{a}$ & $1,60 \mathrm{ab}$ \\
Tirosin & $0,89 \mathrm{a}$ & $0,73 \mathrm{a}$ & $0,65 \mathrm{a}$ & $0,67 \mathrm{a}$ \\
Valin & $1,08 \mathrm{~b}$ & $1,21 \mathrm{a}$ & $1,12 \mathrm{a}$ & $1,19 \mathrm{a}$ \\
Phenilalanin & $1,53 \mathrm{a}$ & $1,46 \mathrm{a}$ & $1,31 \mathrm{a}$ & $1,51 \mathrm{a}$ \\
Isoleusin & $1,06 \mathrm{a}$ & $1,01 \mathrm{a}$ & $1,01 \mathrm{a}$ & $1,03 \mathrm{a}$ \\
Leusin & $1,85 \mathrm{a}$ & $1,89 \mathrm{a}$ & $1,76 \mathrm{a}$ & $1,99 \mathrm{a}$ \\
Methionin & $0,73 \mathrm{a}$ & $0,73 \mathrm{a}$ & $0,72 \mathrm{a}$ & $0,73 \mathrm{a}$ \\
Total & 7,65 & 8,58 & 8,22 & 8,72 \\
Asam & & & & \\
Asam aspartat & $3,99 \mathrm{~b}$ & $4,35 \mathrm{~b}$ & $4,43 \mathrm{~b}$ & $3,83 \mathrm{a}$ \\
Asam glutamat & $15,95 \mathrm{c}$ & $15,11 \mathrm{~b}$ & $14,6 \mathrm{a}$ & $15,14 \mathrm{~b}$ \\
Serin & $1,41 \mathrm{a}$ & $1,28 \mathrm{a}$ & $1,37 \mathrm{ab}$ & $1,46 \mathrm{~b}$ \\
Histidin & $0,83 \mathrm{ab}$ & $0,82 \mathrm{a}$ & $0,79 \mathrm{ab}$ & $0,82 \mathrm{~b}$ \\
Total & 22,18 & 21,56 & 21,05 & 21.25 \\
\hline
\end{tabular}

Keterangan: Huruf berbeda di belakang angka pada baris sama menunjukkan beda nyata pada $p \leq 0,05$

Hasil rata-rata 2 ulangan dengan 3 ulangan analisis

enzimatik dan non enzimatik setelah kematian biji (13). Hasil penelitian ini sesuai dengan hasil yang diperoleh Misnawi et al, (2002) yang mempelajari aktivitas enzim pada biji kakao kering terhadap pembentukan prekursor flavor (7).
Hasil analisis asam amino tersaji pada Tabel 1. Pada perlakuan kontrol, IA dan IB menunjukkan bahwa protein biji kakao kering mengalami degradasi selama fermentasi menjadi asam amino hidrofobik seperti alanin, valin, tirosin, phenialanin, 
isoleusin, leusin dan methionin. Hasil penelitian ini menunjukkan bahwa kandungan asam amino hidrofobik pada perlakuan kontrol adalah alanin, tirosin, valin, phenilalanin, isoleusin, leusin, dan methionin, di awal fermentasi berturut - turut yaitu 0,$72 ; 0,78 ; 0,82 ; 1,26 ; 0,92$ dan $0,65 \mu \mathrm{g} / \mathrm{g}$. Pada 72 jam fermentasi turun menjadi berturut - turut 1,$32 ; 0,69 ; 0,95 ; 1,18 ; 0,87 ; 1,47$ dan $0,64 \mu \mathrm{g} / \mathrm{g}$. Ditinjau dari keberhasilan proses fermentasi semua perlakuan diduga ada aktivitas mikrobia endogenous mendegradasi asam amino menjadi asam amino bebas hidrofobik. Asam amino hidrofobik biji kakao naik sejalan dengan lama fermentasi yang dikendalikan oleh aktivitas enzim aspartat protease dan karboksi peptidase (14).

Selama proses fermentasi, di akhir proses diharapkan asam amino hidrofobik naik, karena asam amino hidrofobik merupakan prekursor aroma khas kakao. Hal ini sejalan dengan penelitian (14-17) yang menyatakan bahwa fermentasi biji kakao telah menurunkan hampir seluruh asam amino kecuali asam amino hidrofobik seperti alanin,tirosin, valin, phenilalanin, isoluesin, leusin dan methionin.

Hasil analisis asam amino perlakuan penambahan inokulum secara serentak menunjukkan bahwa total asam amino hidrofobik dan asam amino di akhir fermentasi berturut - turut yaitu 8,26 dan $21,41 \mu \mathrm{g} / \mathrm{g}$. Secara umum, terjadi peningkatan pada asam amino hidrofobik tetapi terjadi penurunan pada asam amino asam seperti tersaji pada Tabel 2. Hasil analisis ANOVA satu arah menunjukkan bahwa kosentrasi alanin perlakuan kontrol berbeda nyata terhadap perlakuan penambahan inokulum secara serentak dan secara bertahap. Pada 96 jam fermentasi, senyawa alanin dan isoleusin naik menjadi 1,66 dan $0,97 \mu \mathrm{g} / \mathrm{g}$, sedangkan senyawa tirosin, valin, phenilalanin, leusin dan methionin turun menjadi berturut - turut yaitu 0,61, 0,99, 1,19, 1,60 dan $0,70 \mu \mathrm{g} / \mathrm{g}$. Pada akhir fermentasi, senyawa alanin turun menjadi $1,61 \mu \mathrm{g} / \mathrm{g}$. Hal ini diduga terjadi adanya terdegradasi lanjut.

Enzim endogenous aspartat endoprotease dan karboksipeptidase berperan penting dalam konversi oligopeptida hidrofobik untuk membentuk senyawa prekursor aroma kakao, sedangkan oligopeptida yaitu hidrofilik dan hidrofobik dihidrolisis menjadi asam amino bebas terutama leusin, valin, alanin, isoleusin, dan phenilalanin yang diperlukan untuk pembentukan komponen senyawa aroma kakao khas bereaksi dengan gula reduksi saat penyangraian (18-22).

Hasil analisis asam amino biji kakao kering perlakuan secara bertahap di akhir fermentasi menunjukkan bahwa total asam amino hidrofobik dan asam amino asam berturut - turut yaitu 8,72 dan $21,25 \mu \mathrm{g} / \mathrm{g}$ yang selengkapnya tersaji pada Tabel 3. Hasil penelitian ini menunjukkan bahwa senyawa alanin, tirosin, valin, phenilalanin, isoleusin, leusin dan methionin di awal fermentasi berturut-turut yaitu 1,59, $0,89,1,08,1,53,1,06,1,85$ dan $0,73 \mu \mathrm{g} / \mathrm{g}$. Pada $72 \mathrm{jam}$ fermentasi senyawa leusin dan valin naik menjadi 1,89 dan $1,21 \mu \mathrm{g} / \mathrm{g}$, sedang senyawa alanin, tirosin, valin, phenilalanin, isoleusin dan methionin turun berturut turut menjadi 1,55, 0,73, 1,46, 1,01 dan $0,73 \mu \mathrm{g} / \mathrm{g}$.

Jika ditinjau dari peningkatan total asam amino pada perlakuan secara bertahap menunjukkan bahwa terjadi peningkatan jumlah total asam amino yang dihasilkan. Hal ini dapat diduga dipolimerisasi pektin oleh enzim poligalakturonase (PGs) selama fermentasi yang menyebabkan kerusakan dinding sel. Difusi asam asetat dan panas, mematikan biji serta mengaktifkan enzim endogenous guna menghidrolisa protein menjadi asam amino hirdofobik lebih banyak.

Dugaan ini diperkuat dengan beberapa penelitian berikut enzim poligalakturonase (PGs) adalah salah satu enzim pektolitik yang pada kondisi suhu $42,5^{\circ} \mathrm{C}$ dan $\mathrm{pH} 4,6$ dapat mendepolimerasi pektin lebih baik (23). Enzim aspartat endopeptidase menghidrolisis ikatan peptida di Vicilin-class globulins (VCG) pada residu asam amino hidrofobik, selanjutnya membentuk oligopeptida hidrofobik sebagai substrat bagi karboksi serin (exo-peptidase) yang memutus gugus karboksil pada residu asam amino hidrofobik setelah kematian biji $(24,25,12,21,26-28)$.

\section{KESIMPULAN}

Perlakuan penambahan inokulum secara bertahap dapat menurunkan kandungan polifenol. 
Kandungan total asam amino bebas hidrofobik dapat dinaikkan melalui fermentasi. Perlakuan penambahan inokulum secara serentak dan penambahan inokulum secara bertahap selama fermentasi dapat diidentifikasi senyawa volatil khas biji kakao yaitu 3 methil butanal, 3 metil butanoat, benzil alkohol dan etil benzoat.

\section{RUJUKAN}

1. Schwan RF. Cocoa fermentations conducted with a defined microbial cocktail inoculum. Appl Environ Microbiol. American Society for Microbiology; 1998 Apr;64(4):1477-83.

2. Owusu. Influence of Raw Material and Processig on Aroma in Chocolate, Ph.D. Thesis. University of Cophenhagen; 2010.

3. Rodriguez-Campos J, Escalona-Buendía HB, Orozco-Avila I, Lugo-Cervantes E, JaramilloFlores ME. Dynamics of volatile and non-volatile compounds in cocoa (Theobroma cacao L.) during fermentation and drying processes using principal components analysis. Food Res Int. 2011 Jan;44(1):250-8.

4. Rodriguez-Campos J, Escalona-Buendía HB, Contreras-Ramos SM, Orozco-Avila I, Jaramillo-Flores E, Lugo-Cervantes E. Effect of fermentation time and drying temperature on volatile compounds in cocoa. Food Chem. 2012 May 1;132(1):277-88.

5. Misnawi, Jinap S. Effect of cocoa bean polyphenols on sensory properties and their changes during fermentation. Pelita Perkeb. 2003;19(2):90-103.

6. Wollgast J, Anklam E. Review on polyphenols in Theobroma cacao: changes in composition during the manufacture of chocolate and methodology for identification and quantification. Food Res Int. 2000 Jul;33(6):423-47.

7. Jinap, Misnawi S, Nazamid S, Jamilah B. Activation of remaining key enzymes in dried under-fermented cocoa beans and its effect on aroma precursor formation. Food Chem [Internet]. 2002;78(4):407-17. Available from: http://linkinghub.elsevier.com/retrieve/pii/ S0308814602001206
8. Ganda Putra G., Harjiono, Susanto T, Kumalaningsih S, Aulanni'am. Optimasi kondisi depolimerisasi pulp biji kakao oleh enzim poligalakturonase endojinus. J Tek Ind. 2008;9(1):124-34.

9. Noor-Soffalina SS, Jinap S, Nazamid S, Nazimah $\mathrm{SAH}$. Effect of polyphenol and $\mathrm{pH}$ on cocoa Maillard-related flavour precursors in a lipidic model system. Int J Food Sci Technol. Blackwell Publishing Ltd; 2009 Jan;44(1):168-80.

10. Ikrawan $Y$, Chaiseri S, Vungdeethum O. Effect of fermentation time on pyrazine concentration of Thai forsero beans. Kasesart J (Natural Sci. 1997;31:479-87.

11. Kustyawati ME, Setyani S. Pengaruh penambahan inokulum campuran terhadap perubahan kimia dan mikrobiologi selama fermentasi coklat. J Teknol dan Ind Has Pertan. 2012;13(2).

12. Apriyanto M. Changes in chemical properties of dreid cocoa ( Theobroma cacao) beans during fermentation. Int J Fermented Foods. 2016;5(1):11.

13. Thomson S., Miller K., LopezA. Cocoa and coffe. In: Doyle P., Bechat LR, Montivile, editors. food microbiology and fundamental and frointers 4th. 4th ed. Woshington DC: T.J. Asm Press; 2000.

14. Kirchoff P., Biehl B, Crone G. Peculiarity of the accumulation of free amino acid during cocoa fermentation. Int Food Res J. 1989;17:763-74.

15. Voigt J, Biehl B, Wazir SKS. The major seed proteins of Theobroma cacao L. Food Chem. 1993 Jan;47(2):145-51.

16. Dodo HW, Fritz PJ, Furtek DB. A cocoa 21 kilo Dalton seed protein has trypsin inhibitory activity. Café Cacao Téa. 1992;36:279-84.

17. Dodo HW, Furtek DB. Cloning andsequencing of a gene encoding a $21 \mathrm{kDa}$ trypsin inhibitor from Theobroma cacao L. Cafe Cocoa. 1994;38:113-7.

18. Voigt J, Biehl B, Heinrichs $\mathrm{H}$. In-vitro formation of cocoa-specific aroma precursors : aroma-related peptides generated from cocoa-seed protein by co-operation of an aspartic endoprotease and a carboxypeptidase. Food Chem. 1994;49:17380. 
19. Biehl B, Heinrichs J, Voigt G, Bytof G, Serrano P. Nature of proteases and their action on storage proteins in cocoa seeds during germination as compared with fermentation. 12 th Cocoa Research Conference, Salvador Lagos, Nigeria: Cocoa Producers Alliance. Salvador. Lagos, Nigeria; 1966. p. 18-23.

20. Kirchhoff, P.M., Biehl, B., Ziegeler-Berghausen, H., Hammoor, M., dan Lieberei M. Kinetics of the formation of free amino acids in cocoa seeds during fermentation. Food Chem. 1989;34:16179.

21. Ziegleder G, Biehl B. Analysis of cocoa flavour components and flavour precursors. In: Lickens HF, Jackson JF, editors. Analysis of Non Alcoholic Beverages, Methods of Plant Analysis, vol 8. Springer Verlag, Heidelberg, Germany; 1988. p. 321-93.

22. Kosim M, Surya RP. Pengaruh suhu pada protease dari bacillus subtilis. Intitut Teknologi Surabaya; 2010.

23. Biehl B, Voigt J. Biochemistry of cocoa flavour precursors. 12th International Cocoa Research
Conference, Salvador, Brazil. Salvador, Brazil: Lagos, Nigeria: Cocoa producers Alliance; 1996. p. 929-38.

24. Heriyawan. Perbaikan proses fermentasi biji kakao kering jemur dengan penambahan kanji yang tepat. Fakultas Pertanian Universitas Gadjah Mada; 2015.

25. Donny Widianto, Ajeng Dara Pramita dan SW. Perbaikan proses fermentasi biji kakao kering dengan penambahan tetes tebu, khamir, dan bakteri asam asetat. J Teknosains. 2013;3(1):38-44.

26. Hansen CE, Olmo M del, Burri C. Enzyme activities in cocoa beans during fermentation. J Sci Food Agric. John Wiley \& Sons, Ltd; 1998 Jun;77(2):273-81.

27. Putranto WS. Aktivitas proteolitik Lactobacillus acidophilus dalam fermentasi susu sapi. J IImu Ternak. 2007;7(1).

28. Pasau C. Efektivitas penggunaan asam asetat pada pemeraman biji kakao segar sebagai analog fermentasi. AGROTEKBIS. 2013;1(2). 